\title{
Antimicrobial cellulose acetate films by incorporation of geranyl acetate for active
}

\section{food packaging application}

\author{
Filmes antimicrobianos de acetato de celulose por incorporação de acetato de geranila para \\ aplicação em embalagens ativas de alimentos \\ Películas de acetato de celulosa antimicrobiano mediante la incorporación de acetato de geranilo
} para su aplicación en envases activos de alimentos

Laura Cassol Mohr Celuppi ORCID: https://orcid.org/0000-0003-3033-7950 Universidade Federal de Santa Catarina, Brazil

E-mail: laura_cmohr@unochapeco.edu.br

Ana Paula Capelezzo

ORCID: https://orcid.org/0000-0001-6667-7186 Universidade Federal de Santa Catarina, Brazil E-mail: ana_cap@unochapeco.edu.br

Letícia Bavaresco Cima

ORCID: https://orcid.org/0000-0002-0473-2423 Universidade Comunitária da Região de Chapecó, Brazil

E-mail: leticia.cima@unochapeco.edu.br

Rubieli Carla Frezza Zeferino

ORCID: https://orcid.org/0000-0002-3562-322X Universidade Comunitária da Região de Chapecó, Brazil

E-mail: rubifrezza@unochapeco.edu.br

Micheli Zanetti

ORCID: https://orcid.org/0000-0001-5218-7522 Universidade Comunitária da Região de Chapecó, Brazil

E-mail: eng.miche@unochapeco.edu.br

Humberto Gracher Riella

ORCID: https://orcid.org/0000-0003-0435-6082

Universidade Federal de Santa Catarina, Brazil E-mail: humberto.riella@ufsc.br

Márcio Antônio Fiori

ORCID: https://orcid.org/0000-0002-4292-2068 Universidade Comunitária da Região de Chapecó, Brazil

E-mail: fiori@unochapeco.edu.br

\begin{abstract}
The development of new antimicrobial polymeric materials is in prominence due to its versatility of applications, especially for the manufacture of active packaging food. Cellulose acetate is an example of polymeric material used to this purpose, due to its characteristics of biodegradability and easy processing, in addition its natural origin and no toxicity. Geranyl acetate is an ester derived from geraniol, which has good antimicrobial properties and good thermal stability, which makes it interesting to be applied as an antimicrobial agent, avoiding the trivial and often problematic metallic nanoparticles and also volatile essential oils. In this work, antibacterial and antifungal cellulose acetate films were obtained through the incorporation of geranyl acetate ester (in concentrations of 0.5 and $1.0 \% \mathrm{v} / \mathrm{v}$ ), by using the casting technique. This new material was tested against gram-positive and gram-negative bacteria and fungi. Results showed that it is possible to obtain antibacterial and antifungal cellulose acetate films with the incorporation of geranyl acetate ester, with excellent antibacterial activity against gram-positive and gram-negative bacteria and good antifungal activity.
\end{abstract}

Keywords: Cellulose acetate; Geranyl acetate; Biodegradable polymer; Antimicrobial material; Active Packaging.

\section{Resumo}

O desenvolvimento de novos materiais poliméricos antimicrobianos está em destaque devido a versatilidade de aplicações, especialmente para a fabricação de embalagens ativas para alimentos. Acetato de celulose é um exemplo de material polimérico utilizado para este propósito em virtude de sua característica biodegradável e de fácil processamento, além de ser de origem natural e não apresentar toxicidade. Acetato de geranila é um éster derivado do geraniol, que possui excelente atividade antimicrobiana e boa estabilidade térmica, o que o torna interessante para ser 
aplicado como agente antimicrobiano, evitando as triviais e muitas vezes problemáticas nanopartículas metálicas e também os óleos essenciais voláteis. Neste trabalho, filmes antibacterianos e antifúngicos de acetato de celulose foram obtidos através da incorporação do éster acetato de geranila (na concentração de 0,5\% e 1,0\% v/v), utilizando a técnica de casting. Este novo material foi testado contra bactérias gram-positivas e gram-negativas e também fungos. Os resultados mostraram que é possível obter filmes antibacterianos e antifúngicos de acetato de celulose com a incorporação do éster acetato de geranila, com excelente atividade antibacteriana contra bactérias gram-positivas e gram-negativas e boa atividade antifúngica.

Palavras-chave: Acetato de celulose; Acetato de geranila; Polímero biodegradável; Material antimicrobiano; Embalagens ativas.

\section{Resumen}

El desarrollo de nuevos materiales poliméricos antimicrobianos se destaca por la versatilidad de aplicaciones, especialmente para la fabricación de envases activos para alimentos. El acetato de celulosa es un ejemplo de material polimérico utilizado para este fin por sus características biodegradables y de fácil procesamiento, además de ser de origen natural y no tener toxicidad. El acetato de geranilo es un éster derivado del geraniol, que tiene una excelente actividad antimicrobiana y una buena estabilidad térmica, lo que lo hace interesante para su aplicación como agente antimicrobiano, evitando nanopartículas metálicas triviales y a menudo problemáticas y también aceites esenciales volátiles. En este trabajo se obtuvieron películas antibacterianas y antifúngicas de acetato de celulosa mediante la incorporación de éster de acetato de geranilo (a una concentración de 0,5\% y 1,0\% v/v), utilizando la técnica de casting. Este nuevo material ha sido probado contra bacterias gram positivas y gram negativas, así como contra hongos. Los resultados mostraron que es posible obtener películas antibacterianas y antifúngicas de acetato de celulosa con la incorporación de éster de acetato de geranilo, con excelente actividad antibacteriana frente a bacterias gram positivas y gram negativas y buena actividad antifúngica.

Palabras clave: Acetato de celulosa; Acetato de geranilo; Polímero biodegradable; Material antimicrobiano; Envasado activo.

\section{Introduction}

The fossil raw materials replacement by renewable alternatives is a trend that contributes to the generation of more suitable materials for the recycling and also that are biodegradable (Zhu et al., 2016). An example are biodegradable polymers/biopolymers, which consist of materials that can be consumed spontaneously, through the action of microorganisms such as naturally occurring bacteria, fungi and algae, along with other processes such as photodegradation, oxidation and hydrolysis, providing a reduction in the accumulation of solid waste in ecosystems (Zhong et al., 2019). Most of these materials use renewable natural biomass as a raw resource for obtaining them, as they have the advantage of reducing the impact on the environment, especially carbon dioxide emissions (Al-Jahwari \& Pervez, 2020).

Currently the major food industries concern is food safety and quality, which is deeply associated with growth inhibition or even complete inactivation of the pathogenic microorganisms presents, such as bacteria and fungi harmful to human and animal health, responsible for reducing the shelf life of food and increase the risk of foodborne illness. In this context, antimicrobial active packages are developed, which are designed to control microbial proliferation through the incorporation of an antimicrobial agent in its composition, making it possible to extend the shelf life of food, maintain food safety and minimize wastage (Glicerina et al., 2021, Krepker et al., 2017). Therefore, developing an antimicrobial polymeric material that can be used to obtain active packaging and also does not harm the environment is a challenge at a global level.

One of the polymers used to make antimicrobial biodegradable films is the cellulose acetate ester (CA), as it is a biocompatible biopolymer, it is non-toxic, has high mechanical resistance and is hydrophilic (Dairi et al., 2019, Jatoi, Kim \& $\mathrm{Ni}, 2019$, Xie \& Hung, 2018). The CA biodegradation has also been investigated in some studies, evaluating, among other things, the polymeric material mass loss under certain conditions of biodegradation and also the biological activity in the degradative process, attesting that this material is, in fact, biodegradable (Ishigaki et al., 2000, Mostafa et al., 2018).

Currently the CA is applied in the manufacture of active food packaging, in which it is the base material for the natural antimicrobial agents incorporation (such as extracts and essential oils) or synthetic (for example, metal oxide nanoparticles), originating films capable of inhibiting the pathogenic microorganisms proliferation, protecting and extending 
the shelf life of the food being packaged (Gutiérrez-García el al., 2021, Dannenberg et al., 2017, Jatoi et al., 2019, Pola et al., 2016, Xie \& Hung, 2018, Xie et al., 2022). However, essential oils have high thermal degradation, starting its degradation in temperatures usually lower than the processing temperatures of polymers, while metallic nanoparticles have toxicity even with low concentrations, such as silver nanoparticles (Tortella et al., 2020).

In this sense, is interesting to use an antimicrobial additive with low volatility, high thermal stability and low toxicity. The compound added to the cellulose acetate polymer was geranyl acetate, an ester derived from geraniol alcohol, widely used by the perfume industry due its organoleptic properties (Xiong et al., 2014), being classified as an edible aroma, present in the list of foods for human consumption, recognized as safe by the Food And Drug Administration (FDA). Geranyl acetate has a higher thermal degradation temperature $\left(242{ }^{\circ} \mathrm{C}\right)$ compared to most natural essential oils, which have a fast mass loss as a function of time and temperature. For orange, lemongrass and basil essential oils, for example, the degradation starts at room temperature, and the evaporation ends at 118.1, 166.7 and $164.2{ }^{\circ} \mathrm{C}$, respectively (Martins et al., 2011).

Thus, the main objective of this work was to obtain an antibacterial cellulose acetate films with the incorporation of the geranyl acetate ester, in the shortage view studies that use an ester as an antimicrobial agent in polymeric materials.

\section{Methodology}

\subsection{Films preparation}

The geranyl acetate ester was synthesized by chemical route catalyzed by a commercial resin by the research group Development and Chemical and Biotechnological Optimization Processes of the Universidade Comunitária da Região de Chapecó - Unochapecó (Zeferino et al., 2021). Cellulose acetate (39.8\% by weight of acetyl, average molar mass of approximately $30.000 \mathrm{~g} / \mathrm{mol}$ ) was purchased from Sigma-Aldrich. These substances were processed in order to obtain polymeric films using the casting technique based on the methodology suggested by Takeuchi et al. (2017) and Gouvêa et al. (2015).

To obtain the films, $0.2 \mathrm{~g}$ of cellulose acetate were diluted in $9 \mathrm{~mL}$ of acetone with geranyl acetate ester in concentrations of 0.5 and $1.0 \%(\mathrm{v} / \mathrm{v})$. The mixture was stirred for 1 hour in a shaker at room temperature and then these solutions were poured into glass plates with a smooth surface. After this process, the plates containing the films were taken to an oven, kept under $50{ }^{\circ} \mathrm{C}$ and a vacuum of $400 \mathrm{mmHg}$ for 3 hours, in order to carry out the acetone evaporation. After the solvent has evaporated, the films were removed from the plates. As a control, films without ester addition were produced (Carvalho, et al., 2017, Gouvêa et al., 2015).

\subsection{Films antimicrobial analysis}

\subsubsection{Evaluation of bacterial growth inhibition on the films surface}

Samples of the cellulose acetate films $(2 \times 2 \mathrm{~cm})$, with and without geranyl acetate, were subjected to the test of counting surviving microorganisms over time (death curve), according to the international standard JIS Z 2801- 10 for the bacteria Staphylococcus aureus and Escherichia coli. The inoculum for the analysis consists of a microbial solution containing $10^{4} \mathrm{CFU} / \mathrm{mL}$, which was sown on the surface of the films, and samples for analysis were collected at $0,1,2,3,6$ and $24 \mathrm{~h}$, evaluating the CFU count up. The number of viable bacteria $/ \mathrm{cm}^{2}$ was determined using Equation 1.

$$
N=\frac{C * D * V}{A}
$$

Where: 
$\mathrm{N}$ : number of viable bacteria/ $\mathrm{cm}^{2}, \mathrm{C}$ : number of colonies (CFU), D: dilution factor (dimensionless); V: volume (mL) of $0,85 \% \mathrm{NaCl}$ solution $(10 \mathrm{~mL})$ and $\mathrm{A}$ : surface area $\left(4 \mathrm{~cm}^{2}\right)$.

\subsubsection{Evaluation of fungi growth inhibition on the films surface}

For the evaluation of the growth inhibition of fungi on the surface of the developed films, the standards JIS Z 2801-10 (adapted for fungi) and ASTM G21-15 were used as basis, using Aspergillus niger as a reference specie. Cellulose acetate films $(2 \times 2 \mathrm{~cm})$ with and without geranyl acetate were inoculated with $40 \mu \mathrm{L}$ of the fungal solution containing $10^{5} \mathrm{spores} / \mathrm{mL}$ and inserted in a petri dish together with $1 \mathrm{~mL}$ of previously sterilized water, with the objective of maintaining the humidity of the environment and enabling the growth of the fungus. The plates containing the inoculated samples were incubated in an oven at $28 \pm 2{ }^{\circ} \mathrm{C}$ for 7 days.

After the incubation period, the film samples were removed from the petri dishes and inserted in a stomacher bag together with $10 \mathrm{~mL}$ of sterile saline water $(0.85 \%)$ for homogenization, in order to extract the microorganisms present on the surface of the samples. A fraction of $1 \mathrm{~mL}$ of the resulting solution was removed and inoculated by depth on Sabouraud agar.

The plates were incubated in an oven at $28 \pm 2{ }^{\circ} \mathrm{C}$ for 7 days and, after the incubation time had elapsed, the plates were evaluated according to fungal growth, using the classification provided by the standard ASTM G21-15. When none growth is observed, the rating is 0 ; traces of growth (less than $10 \%$ ), the rating is 1 ; for light growth (10 to $30 \%$ ), medium growth (30 to 60\%) and heavy growth (60\% to complete coverage) the ratings are 2, 3 and 4, respectively.

\section{Results and Discussion}

\subsection{Evaluation of bacterial growth inhibition on the films surface:}

In order to evaluate the antibacterial potential of cellulose acetate films incorporated with geranyl acetate ester, the death curve test was performed. This methodology is the most designed to evaluate an antimicrobial capacity of polymeric films, considering that it evaluates the growth of bacteria on the surface of these materials over time. Figure 1 illustrates the result of this test for Staphylococcus aureus (a) and Escherichia coli (b), respectively, with inoculum at a concentration of $10^{4}$ $\mathrm{CFU} / \mathrm{mL}$.

Figure 1. Results obtained with the death curve test for the polymeric films containing $0 \%$ (control) and $0.5 \%$ geranyl acetate for (a) Staphylococcus aureus and (b) Escherichia coli.
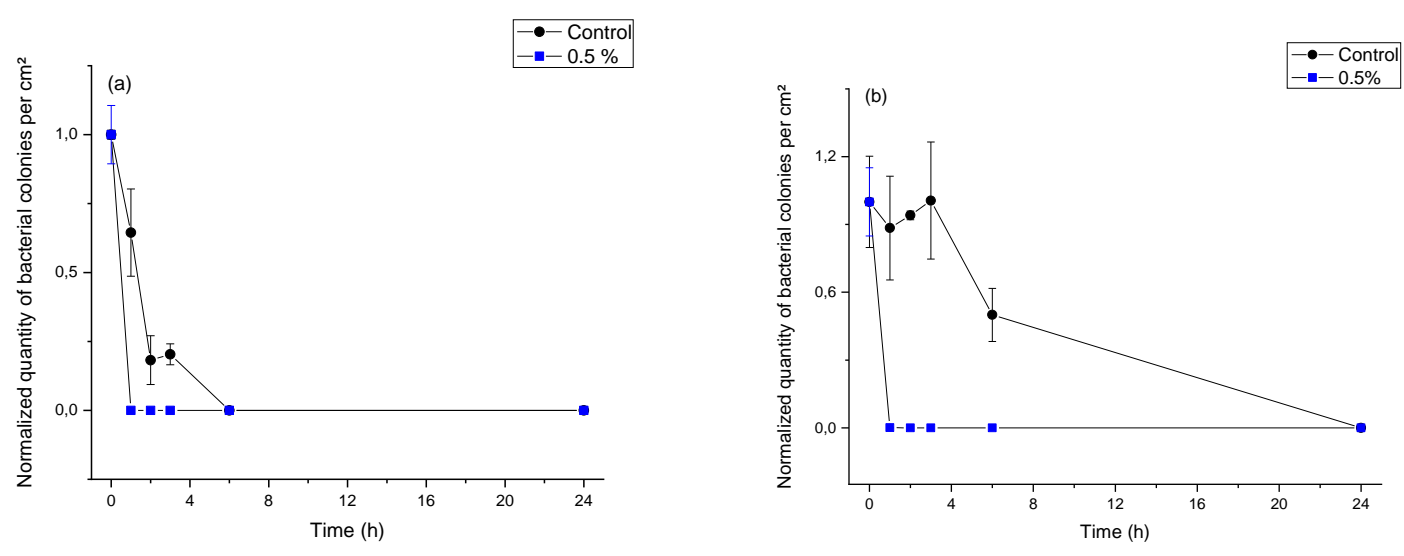

Source: Authors. 
As seen in Figure 1, cellulose acetate antimicrobial films containing $0.5 \%$ geranyl acetate were very efficient, both for the gram-positive bacteria Staphylococcus aureus (a) and for the gram-negative bacteria Escherichia coli (b). The samples had a lower bacterial count compared to the film without antimicrobial agent (control) during the time that the cells were viable. In addition, it appears that in one hour, for both bacteria, the cell count was practically null, and this behavior was also verified in the other sampled times, showing that the cellulose acetate film containing $0.5 \%$ geranyl acetate eliminates bacteria on its surface. Therefore, it shows an excellent antibacterial material, effective for gram-positive as well as gram-negative bacteria.

This fact is best observed with the results shown in Table 1 (data were subjected to the analysis of variance (ANOVA) to determine the significant difference between the means; means multiple comparisons were performed using Tukey test at a significance level of 0.05). Initially (time 0) there was a high bacterial cell count for both films analyzed. After 1 hour, the count of normalized quantity of bacterial colonies per $\mathrm{cm}^{2}$ for films containing $0.5 \%$ geranyl acetate is null or practically null, that is, this film not only inhibits bacterial growth but also eliminates all bacteria present on its surface - whether they are gram-positive or gram-negative - showing the high antibacterial efficiency of this material.

Table 1. Bacterial count for the different times sampled in the death curve test for the polymeric films.

\begin{tabular}{ccc|cc}
\hline \multirow{2}{*}{ Time (h) } & \multicolumn{3}{c}{ Normalized quantity of bacterial colonies per $\mathbf{c m}^{2}$} \\
\hline & \multicolumn{2}{c}{ Staphylococcus aureus } & \multicolumn{2}{c}{ Escherichia coli } \\
\cline { 2 - 5 } & $0 \%($ control) & $0.5 \%$ & $0 \%$ (control) & $0.5 \%$ \\
\cline { 2 - 5 } 0 & $1.00 \pm 0.02^{\mathrm{Aa}}$ & $1.00 \pm 0.11^{\mathrm{Aa}}$ & $1.00 \pm 0.20^{\mathrm{Aa}}$ & $1,00 \pm 0.15^{\mathrm{Aa}}$ \\
1 & $0.64 \pm 0.16^{\mathrm{Ab}}$ & $0.00 \pm 0.00^{\mathrm{Bb}}$ & $0.88 \pm 0.23^{\mathrm{Aa}}$ & $9.90 \times 10^{-4} \pm 1.70 \times 10^{-3 \mathrm{Bb}}$ \\
2 & $0.18 \pm 0.09^{\mathrm{Ac}}$ & $0.00 \pm 0.00^{\mathrm{Bb}}$ & $0.94 \pm 0.02^{\mathrm{Aa}}$ & $0.00 \pm 0.00^{\mathrm{Bb}}$ \\
6 & $0.20 \pm 0.04^{\mathrm{Ac}}$ & $0.00 \pm 0.00^{\mathrm{Bb}}$ & $1.00 \pm 0.26^{\mathrm{Aa}}$ & $0.00 \pm 0.00^{\mathrm{Bb}}$ \\
24 & $0.00 \pm 0.00^{\mathrm{Ad}}$ & $0.00 \pm 0.00^{\mathrm{Ab}}$ & $0.50 \pm 0.12^{\mathrm{Ab}}$ & $0.00 \pm 0.00^{\mathrm{Bb}}$ \\
\hline
\end{tabular}

* Equal lowercase letters represent that there are no significant differences between lines $(\mathrm{p}<0.05)$ and equal uppercase letters represent that there are no significant differences between columns $(\mathrm{p}<0.05)$. Source: Authors.

Another interesting fact is that, during the analysis time, there is a reduction in the quantity of viable cells of Staphylococcus aureus on the polymer surface without the addition of geranyl acetate (control). Within 6 hours, there were no more viable cells. This behavior was already expected because it is natural for bacteria to die after some time, due to the absence of nutrients and of water on the surface, which are essential for the survival of these microorganisms (Tortora et al., 2017). It is worth mentioning that, in the time of 1 hour, the reduction of the reference film (control) was only 35.53\% while the reduction for the film containing the antimicrobial agent was $100.00 \%$ (Table 2,) that is, the film is highly efficient to prevent microbial growth.

Table 2. Percentage of reduction in bacterial count after 1 hour of contact with polymeric films.

\begin{tabular}{lcc}
\hline Sample & \multicolumn{2}{c}{ Growth reduction $(\boldsymbol{\%})$} \\
\hline & Staphylococcus aureus & Escherichia coli \\
\cline { 2 - 3 } $0 \%($ control) & 35.52 & 11.58 \\
$0.5 \%$ & 100.00 & 99.90 \\
\hline
\end{tabular}

Source: Authors.

A similar behavior was observed when Escherichia coli was inoculated in the polymer without the addition of ester (control), however, a statistically significant reduction in growth was observed only after 6 hours, with the number of colonies remaining constant until this time, showing the lower susceptibility of gram-negative bacteria to external agents, affirming the 
greater resistance of this class of bacteria, which, in the time of 1 hour, showed a reduction of only 11.58\% (Table 2) in the count of their viable cells. This difference between gram-positive and gram-negative bacteria can be explained because the cell structure of gram-positive and gram-negative bacteria is not the same. While the cells of gram-positive bacteria have only one outer layer, gram-negative bacteria have an additional second membrane, with a phospholipid bilayer structure, which provides additional protection for the inner cytoplasmic membrane. Thus, gram-positive bacteria are more susceptible to the penetration of external molecules in their cells, which makes them more fragile, and justifies the lower microbial count on the material surface for the Staphylococcus aureus bacteria (Muñoz-Bonilla \& Fernández-García, 2012). It is important to show that the reduction for this class of bacteria, in the referred time, was $99.90 \%$ (Table 2,) that is, the film is also efficient for gramnegative bacteria.

Some studies have already been carried out using cellulose acetate as a polymeric base to obtain antimicrobial films through the incorporation of several antimicrobial agents such as thymol (Dairi et al., 2019) and rosemary and aloe essential oils (El Fawal et al., 2019) and these materials, when evaluated by different methodologies, have showed antibacterial activity against gram-positive bacteria and gram-negative bacteria, showing that the cellulose acetate is an excellent matrix for receiving different antimicrobial agents, which was also evidenced in the present study.

In view of the excellent performance of the cellulose acetate film containing $0.5 \%$ geranyl acetate, which has inhibited bacterial growth in just 1 hour of contact, the evaluation of the film with $1.0 \%$ of geranyl acetate is irrelevant, because the antibacterial activity of the cellulose acetate film containing a lower concentration of geranyl acetate can already be considered excellent.

\subsection{Evaluation of fungi growth inhibition on the films surface}

The fungus Aspergillus niger was the microorganism used to evaluate the ability of the developed films to inhibit fungal growth on its surface. Figure 2 shows the microbiological results of growth of the fungus on the films surface containing $0 \%$ (control) $0.5 \%$ and $1.0 \%$ of geranyl acetate.

Figure 2. Results obtained with the analysis of the growth of the fungus Aspergillus niger on the surface of the polymeric films; (a) $0 \%$ (control), (b) $0.5 \%$ and (c) $1.0 \%$ of geranyl acetate.

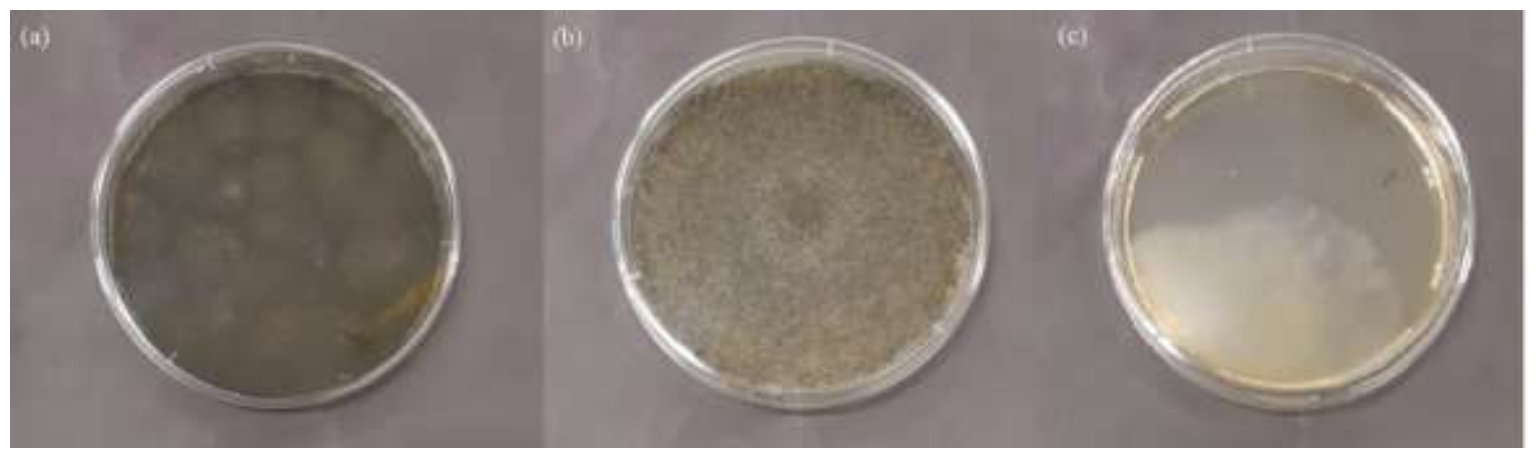

Source: Authors.

For the film without the addition of the antimicrobial agent, the fungus Aspergillus niger grew abundantly, receiving the maximum classification on the growth rating (Table 3), completely filling the plate surface. However, when the fungus was inoculated in the film containing $0.5 \%$ antimicrobial ester, it is clear that the growth of the microorganism was lower, receiving a rating of 3 on the scale (Table 3). This rate was assumed because, according to Figure 2 (b), it is possible to observe that the 
cell density is much lower, showing the capacity to reduce fungal growth on the film surface containing ester in a concentration of $0.5 \%$, this reduction being associated with the presence of the antimicrobial agent.

Table 3. Growth rating for the fungus Aspergillus niger on the polymeric films.

\begin{tabular}{lc}
\hline Sample & Rating \\
\hline $0 \%$ (control) & 4 \\
$0.5 \%$ & 3 \\
$1.0 \%$ & 1 \\
\hline
\end{tabular}

Source: Authors.

This fact is corroborated with Figure 2 (c), showing the fungal growth of the film that contains a higher concentration of ester $(1.0 \%)$. This condition can be classified as 1 on the growth scale (Table 3), because it shows only traces of growth of the fungus Aspergillus niger, with surface coverage of less than $10 \%$ of the plate. Therefore, an excellent antifungal activity was detected in the cellulose acetate film containing $1.0 \%$ geranyl acetate.

In a similar study, Dairi et al. (2019) have obtained a polymeric material based on cellulose acetate (among other materials), with the incorporation of thymol as an antimicrobial agent. These films, in addition to showing antibacterial activity, have also showed good results as antifungal materials, showing greater activity against the growth of Aspergillus niger in the concentration of $8.0 \%$ of antimicrobial agent.

For the material developed, both antifungal and antibacterial activity were achieved with low concentrations of geranyl acetate ester, which is an important consideration, given that, as a rule, the antimicrobial agent implies an additional cost to the material developed. Therefore, the smaller the amount of the antimicrobial agent, the more interesting and competitive the antimicrobial cellulose acetate films will appear.

\section{Conclusion}

The casting technique made it possible to obtain a new polymeric cellulose acetate material incorporated with the antimicrobial ester geranyl acetate, which showed antimicrobial activity against fungal e bacterial. This result is very interesting, because it allows the use of this new antimicrobial material for applications in active food packaging. In this context, the present work encourages and directs other studies involving for example, the thermal and mechanical films characterization, studies of the ester release from the polymer matrix and also evaluation of the ester influence on the biodegradation of cellulose acetate films.

\section{Acknowledgments}

The authors acknowledge Universidade Comunitária da Região de Chapecó (UNOCHAPECÓ) for the structure to accomplish this work and also Coordination for the Improvement of Higher Education Personnel (CAPES, Brazil) for financial support.

\section{References}

Al-Jahwari, F. S., \& Pervez, T. (2020). The Potential of Environmental-Friendly Biopolymers as an Alternative to Conventional Petroleum-Based Polymers. Encyclopedia of Renewable and Sustainable Materials, 200-206. https://doi.org/10.1016/B978-0-12-803581-8.11295-0

American Society for Testing and Materials - ASTM G21-15 Standard Practice for Determining Resistance of Synthetic Polymeric Materials to Fungi, 2015.

Carvalho, D. de M., Takeuchi, K. P., Geraldine, R. M., Moura, C. J. de, \& Silveira, M. F. A. (2017). Filme ativo de acetato de celulose incorporado com nanosuspensão de curcumina. Polímeros, 27(spe), 70-76. https://doi.org/10.1590/0104-1428.2232 
Dairi, N., Ferfera-Harrar, H., Ramos, M., \& Garrigós, M. C. (2019). Cellulose acetate/AgNPs-organoclay and/or thymol nano-biocomposite films with combined antimicrobial/antioxidant properties for active food packaging use. International Journal of Biological Macromolecules, 121, 508-523. https://doi.org/10.1016/J.IJBIOMAC.2018.10.042

Dannenberg, G. da S., Funck, G. D., Cruxen, C. E. dos S., Marques, J. de L., Silva, W. P. da, \& Fiorentini, Â. M. (2017). Essential oil from pink pepper as an antimicrobial component in cellulose acetate film: Potential for application as active packaging for sliced cheese. LWT - Food Science and Technology, 81, 314-318. https://doi.org/10.1016/J.LWT.2017.04.002

El Fawal, G. F., Omer, A. M. \& Tamer, T. M. (2019). Evaluation of antimicrobial and antioxidant activities for cellulose acetate films incorporated with Rosemary and Aloe Vera essential oils. Journal of Food Science and Technology, 56, 1510-1518. https://doi.org/10.1007/s13197-019-03642-8

Food And Drug Administration (FDA). Title 21 - Food and drugs. Chapter I - Food and drug administration, department of health and human services. Subchapter B - Food for human consumption (continued). Part 182 - Substances generally recognized as safe.

Tortora, G. J., Funke, B. R., \& Case, C. L. Microbiologia. (12a ed.), Artmed, 2017. p. 935.

Glicerina, V., Siroli, L., Canali, G., Chinnici, F., Capelli, F., Lanciotti, R., Colombo, V., \& Romani, S. (2021). Efficacy of biodegradable, antimicrobial packaging on safety and quality parameters maintenance of a pear juice and rice milk-based smoothie product. Food Control, 128, 108170. https://doi.org/10.1016/J.FOODCONT.2021.108170

Gouvêa, D. M., Mendonça, R. C. S., Soto, M. L., \& Cruz, R. S. (2015). Acetate cellulose film with bacteriophages for potential antimicrobial use in food packaging. LWT - Food Science and Technology, 63(1), 85-91. https://doi.org/10.1016/J.LWT.2015.03.014

Gutiérrez-García, G. J., Quintana-Romero, L. A., Morales-Figueroa, G. G., Esparza-Romero, J., Pérez-Morales, R., López-Mata, M. A., Juárez, J., SánchezEscalante, J. J., Peralta, E., Quihui-Cota, L., \& Soto-Valdez, H. (2021). Effect of Yucca baccata butanolic extract on the shelf life of chicken and development of an antimicrobial packaging for beef. Food Control, 127, 108142. https://doi.org/10.1016/J.FOODCONT.2021.108142

Ishigaki, T., Sugano, W., Ike, M., \& Fujita, M. (2000). Enzymatic degradation of cellulose acetate plastic by Novel degrading bacterium Bacillus sp. S2055. Journal of Bioscience and Bioengineering, 90(4), 400-405. https://doi.org/10.1016/S1389-1723(01)80008-6

Jatoi, A. W., Kim, I. S., \& Ni, Q. Q. (2019). Cellulose acetate nanofibers embedded with AgNPs anchored TiO2 nanoparticles for long term excellent antibacterial applications. Carbohydrate Polymers, 207, 640-649. https://doi.org/10.1016/J.CARBPOL.2018.12.029

JIS Z 2801:2010. Antibacterial products - Test for antibacterial activity and efficacy.

Krepker, M., Shemesh, R., Danin Poleg, Y., Kashi, Y., Vaxman, A., \& Segal, E. (2017). Active food packaging films with synergistic antimicrobial activity. Food Control, 76, 117-126. https://doi.org/10.1016/J.FOODCONT.2017.01.014

Martins P., Sbaite P., Benites C., \& Wolf Maciel M., 2011, Thermal Characterization of Orange, Lemongrass, and Basil Essential Oils. Chemical Engineering Transactions, 24, 463-468. https://doi.org/10.3303/CET1124078

Mostafa, N. A., Farag, A. A., Abo-dief, H. M., \& Tayeb, A. M. (2018). Production of biodegradable plastic from agricultural wastes. Arabian Journal of Chemistry, 11(4), 546-553. https://doi.org/10.1016/J.ARABJC.2015.04.008

Muñoz-Bonilla, A., \& Fernández-García, M. (2012). Polymeric materials with antimicrobial activity. Progress in Polymer Science, 37(2), 281-339. https://doi.org/10.1016/J.PROGPOLYMSCI.2011.08.005

Pola, C. C., Medeiros, E. A. A., Pereira, O. L., Souza, V. G. L., Otoni, C. G., Camilloto, G. P., \& Soares, N. F. F. (2016). Cellulose acetate active films incorporated with oregano (Origanum vulgare) essential oil and organophilic montmorillonite clay control the growth of phytopathogenic fungi. Food Packaging and Shelf Life. https://doi.org/10.1016/j.fps1.2016.07.001

Tortella, G. R., Rubilar, O., Durán, N., Diez, M. C., Martínez, M., Parada, J., \& Seabra, A. B. (2020). Silver nanoparticles: Toxicity in model organisms as an overview of its hazard for human health and the environment. Journal of Hazardous Materials, 390,121974 https://doi.org/10.1016/J.JHAZMAT.2019.121974

Xie, J., \& Hung, Y. C. (2018). UV-A activated TiO2 embedded biodegradable polymer film for antimicrobial food packaging application. LWT, 96, 307-314. https://doi.org/10.1016/J.LWT.2018.05.050

Xie, Y., Pan, Y., \& Cai, P. (2022). Cellulose-based antimicrobial films incroporated with $\mathrm{ZnO}$ nanopillars on surface as biodegradable and antimicrobial packaging. Food Chemistry, 368, 130784. https://doi.org/10.1016/J.FOODCHEM.2021.130784

Xiong, J., Huang, Y., Zhang, H., \& Hou, L. (2014). Lipase-Catalyzed Transesterification Synthesis of Geranyl Acetate in Organic Solvents and Its Kinetics. Food Science and Technology Research, 20(2), 207-216. https://doi.org/10.3136/fstr.20.207

Zeferino, R. C. F., Piaia, V. A. A., Orso, V. T., Pinheiro, V. M., Zanetti, M., Colpani, G. L., Padoin, N., Soares, C., Fiori, M. A., \& Riella, H. G. (2021). Synthesis of geranyl acetate by esterification of geraniol with acetic anhydride through heterogeneous catalysis using ion exchange resin. Chemical Engineering Research and Design, 168, 156-168. https://doi.org/10.1016/J.CHERD.2021.01.031

Zhong, Y., Godwin, P., Jin, Y., \& Xiao, H. (2019). Biodegradable Polymers and Green-based Antimicrobial Packaging Materials: A mini-review. Advanced Industrial and Engineering Polymer Research. https://doi.org/10.1016/J.AIEPR.2019.11.002

Zhu, Y., Romain, C. \& Williams, C. (2016). Sustainable polymers from renewable resources. Nature, 354-362. https://doi.org/10.1038/nature21001 